International Journal of Linguistics, Literature and Translation

ISSN: 2617-0299 (Online); ISSN: 2708-0099 (Print)

DOI: $10.32996 / \mathrm{ijllt}$

Journal Homepage: www.al-kindipublisher.com/index.php/ijllt

\title{
Religious Binomials in Hebrew and Arabic: A Review of Literature
}

\author{
Ghuzayyil Mohammed Al-Otaibi 8 (D) $\square$ \\ Lecturer, College of Languages \& Translation, King Saud University, Riyadh, Saudi Arabia \\ Corresponding Author: Ghuzayyil Mohammed Al-Otaibi, E-mail: galotaibi@ksu.edu.sa
}

\section{ARTICLE INFORMATION \\ Received: February 09, 2021 \\ Accepted: March 22, 2021 \\ Volume: 4 \\ Issue: 3 \\ DOI: $10.32996 / i j l t .2021 .4 .3 .24$}

\section{KEYWORDS}

Arabic, binomials, Hebrew, religious, the Bible

\section{ABSTRACT}

Binomials (i.e., a collocation of two connected words belonging to the same word class, e.g., heaven and earth) are very frequent in every language. They are more commonly found in religious texts of Semitic languages. Compared to other types of collocations, religious binomials are sometimes idiomatic, alliterative, culture-specific, or adhere to one common word order. However, as there is a dearth of studies on religious binomials in Hebrew, there is only one study on religious Arabic binomials used in a supplication. Studies on Hebrew focused on the constraints determining the order of binomial words, their semantic and grammatical categorization, how frequent they are, their functions, etc. Corpus-based studies on Semitic binomials were conducted for the purpose of proving that Semitic languages are similar. Nevertheless, there are no studies that explored religious binomials in Arabic in relation to those used in Hebrew. Thus, it might be insightful if future research on binomials focuses on religious ones in the Holy Qur'ān and Hadīth.

\section{Introduction}

Binomials (i.e., a collocation of two connected words belonging to the same word class; Malkiel, 1959) are very frequent in every language. As reported by Mollin (2014), there are about 700,000 tokens of binomials in the British National Corpus (BNC). Despite their pervasiveness, binomials are listed in monolingual dictionaries only if they are idiomatic or irreversible (Carvalho, 2008; Mollin, 2014). Therefore, they are problematic structures for learners and translators because of their idiomaticity (e.g., odds and ends) and cultural properties (e.g., religious binomials such as هَارُوتَ وَمَارُوتَ / 'Harut and Marut'). More significantly, bilingual dictionaries do not provide information on their potential equivalents (Hamdan \& Abu Guba, 2007). Moreover, most of research has concentrated on English (e.g., Copestake \& Herbelot, 2011; Green \& Birdsong, 2018; Lohmann, 2012; Mollin, 2012; Pinker \& Birdsong, 1979), especially on the constraints dictating their order, what effect preferred order has on reading speed, and a detailed analysis of such constructions. Speaking of Arabic, a small number of scholars have explored Arabic binomials (e.g., Al-Jarf, 2016; Ammari, 2015; Gorgis \& Al-tamimi, 2005; Kaye, 2015; Saaed, 2010) in relation to their semantic and grammatical categories, principles governing their order, and how they have been translated by English as a Foreign Language $(E F L)$ learners. As noted above, binomials are under-researched, especially in relation to Arabic and religious texts. Thus, since Arabic and Hebrew are Semitic languages and binomials are found more commonly in such languages and their religious texts, the purpose of the present review of literature is to highlight the importance of examining binomials in Arabic religious texts such as the Holy Qur'ān and Hadīth.

\section{Terminology}

Scholars investigating binomials have used different terms (Mollin, 2014) for such constructions. Thus, linguists disagreed over the term "binomials," which have by used by many researchers (Bolinger, 1962; Gustafsson, 1984; Kadi, 1988; Saaed, 2010; Kopaczyk \& Sauer, 2017) following Malkiel (1959), and hence they were variously labeled "freezes" (Cooper \& Ross, 1975; Oden \& Lopes, 1981; Gil, 1988), "conjoined lexical pairs" (Bakir, 1999; Gorgis \& Al-tamimi, 2005), "contrastive lexical couples" (Gorgis \& Al-tamimi, 2005), "conjoined phrases" (Tiersma, 1999), "word pairs" (Tani, 2008, 2010a), "doublets" (Asensio, 2003; Tani, 2010b), and "Siamese twins" (later conjoined twins by Fowler, 1965). However, such labels do not describe exactly Malkiel's (1959) definition of binomials.

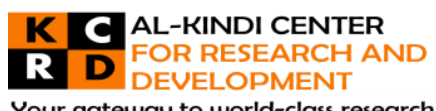

Your gateway to world-class research

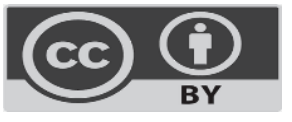

Published by Al-Kindi Center for Research and Development, United Kingdom. Copyright (c) the author(s). This open access article is distributed under a Creative Commons Attribution (CC-BY) 4.0 license 
According to Kopaczyk and Sauer (2017), labels used to describe binomials are sometimes misleading. For example, the term conjoined phrases may stand for longer constructions. On the other hand, the label word pairs generally refers to any type of collocation, whereas doublets has been used by linguists to refer to equivalents in translation (Borchers, 2007).

Other terms, including tautological pairs or repetitive pairs (Leisi, 1947; Koskenniemi, 1968), may exclude contrasting binomials while paired opposites (Cummings, 1980) is restricted to antonyms without any consideration of other types of binomials. It is important to note that the terms formulae, fixed coordinates and freezes (Abraham, 1950; Cooper \& Ross, 1975; Birdsong, 1995; Fenk-Oczlon, 1989; Landsberg, 1995) draw attention to the formulaic or fixed nature of binomials (Kopaczyk \& Sauer, 2017). However, not all binomials exhibit fixedness in the order of their conjuncts because diachronic corpus investigations have indicated that changes in the preferred order of elements are possible and determined by genre type (Mollin, 2014). Regardless of the label used to describe them, researchers agree with Malkiel (1959) who defined them as "a sequence of two words pertaining to the same form-class, placed on an identical level of syntactic hierarchy, and ordinarily connected by some kind of lexical link" (p. 113).

The terms binomials, doublets and freezes have been translated in Ramzi Baalbaki's Dictionary of Linguistic Terms (1990) as (الصنائيات الاسمية / al-thuna'yāt al-ismīyah), (المتماسكان / al al-mutamāskān), respectively. For the present study, the term (الثنائيات / al-thuna'yāt) was adopted as the best translation of binomials since (الثنائيات الاسمية / al-thuna'yāt al-ismìyah) focuses only on the nominal type of binomials, and (المتماسكان / al-mutamāskān) best describes freezes, another group of binomials. More importantly, Jasim (2009) reported that binomials have been examined by many Arab scholars who referred to them as instances of Al-Taqabul (i.e., coordinated converses of temporal, spatial or reciprocal relations, e.g., اللَّيَل وَالنَّهار / al-layl wa-al-nahār ) and Al-Ṭibāq (i.e., coordinated individual words of antonyms that can

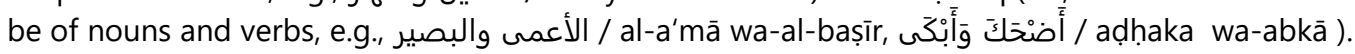

\section{Methodological Approches to Binomials}

Interest in binomials is not recent. Such constructions were analyzed and explored under various terms in English and German. A large body of research is on constraints governing their word order, and the category of binomials under investigation is irreversible binomials. According to Lohmann (2014), previous work on binomials followed one of the three methodological approaches: (a) impressionistic (i.e., a bit intuitive relying on a few examples, e.g., Malkiel, 1959), (b) experimental (i.e., psycholinguistic where data collected using judgment, production, or recognition tasks, e.g., Pinker \& Birdsong, 1979), and (c) corpus based (i.e., using a big amount of electronic data, e.g., Gustafsson, 1975). However, the focus of this section is on corpusbased studies analyzing Arabic and Hebrew binomials in terms of semantic and grammatical categories and ordering constraints since binomials are considered an important feature of religious texts in Semitic languages.

\section{Religious Binomials in Hebrew}

Studies on religious binomials focused mainly on word pairs found in the Hebrew Bible. Such studies did not consider only binomials but also phrases and word groups in parallel structures. Speaking of their scope, Avishur (1984) wanted to prove how Semitic languages are similar because they share a number of binomials. However, the purpose of studies by Duke (2003) and Tvedtnes (1997) is to prove that the Book of Mormon is based on the Hebrew Bible, whereas Talshir (2013) listed the constraints that determine word order. It is important to note that all the mentioned studies are roughly corpus based. That is, Duke (2003) and Tvedtnes (1997) explored the Book of Mormon (i.e., scriptures of a religious group whose religion was founded by Joseph Smith in the US in 1830) which is of approximately 200,000 words, whereas Talshir (2013) investigated Late Biblical Hebrew, Classical Hebrew, Qumran (i.e., manuscripts discovered near Qumran), and two literatures (e.g., Tannaitic literature and Amoraic literature). On the other hand, Avishur (1984) listed religious word pairs found in Hebrew, Ugaritic (i.e., an ancient, extinct dialect of the Amorite language spoken between the $14^{\text {th }}$ and the $12^{\text {th }}$ century BC in Syria), Phoenician, Aramaic, Akkadian, Ammonite (i.e., an extinct Canaanite language), and the Bible. This section reviews studies by Duke (2003), Talshir (2013), and Landau (2017).

One of the oldest studies in the literature on religious binomials is by Avishur (1984) who listed word pairs common in the literatures of old Semitic languages (i.e., Hebrew, Ugaritic, Phoenician, Aramaic, Akkadian, Ammonite) and the Bible. The word pairs that were investigated were sometimes of body parts or proper names. Some are considered universal and found in Arabic (e.g., sun and moon, death and life, the earth and the sky, silver/gold, their eyes and their ears). As reported by Avishur (1984), the interest in studying binomials was because of their prosodic nature and their contribution to poetic parallelism, one of the characteristics of ancient Semitic literature. Additionally, he drew the attention to their relevance to Biblical studies since they may yield results in relation to lexicography, style, and exegesis. Avishur (1984) emphasized the importance of exploring binomials because they can provide answers to geographical questions or explanations to theological issues. He examined such word pairs as they occurred as binomial conjuncts or in parallel structures. The majority of the analyzed word pairs are nouns, and a few are verbs or adjectives. He also discussed reversible binomials. He noted that half of the pairs appeared in Semitic languages, and the other half reflected some literary affinity found in such languages. Based on findings, Hebrew is more related to Phoenician than Ugaritic. 
Another similar study by Tvedtnes (1997) examined word groups (i.e., a sequence of three, four, five, or six words) in the Book of Mormon, and how such word groups relate the Book to the Biblical literature. Tvedtnes (1997) divided them into categories: (a) precious metals (e.g., gold/silver), (b) animals (e.g., flocks/herds), and (c) war weapons such as sword, spear, and dart. As mentioned above, Duke (2003) explored word pairs in the Book of Mormon. He reported that the Book of Mormon conformed to the principles of Hebrew Literature in terms of the use of conjoined and parallel word pairs. Duke (2003) focused on parallel and conjoined word pairs and differentiated between the two claiming that conjoined word pairs are connected with a conjunction, such as and, and occurred adjacent to one another and appeared on the same line. An example is good and evil which is used 17 times in the Bible and 24 times in the Book of Mormon. Additionally, he considered word pairs of four occurrences and more and included in the analysis triplets (i.e., three complementary words), quadruplets (i.e., four complementary words), other word groups such as prepositional phrases, and combinations of adjectives and nouns. According to Duke (2003), triplets and quadruplets are essentially of the complementary type because such sequences of words (e.g., grain/wine/oil) are never listed in a thesaurus; hence, they did not represent the category of synonyms.

Duke (2003) noted that there are a number of functions that word pairs can serve. For example, they are used to maintain potential readers' attention because of their alliterative nature. Additionally, some pairs are used to repeat elements relevant to the Law of Moses (e.g., performances and ordinances). Other word pairs, however, are employed for theological significance (i.e., true/living God, flesh/blood, justice/mercy). Additionally, some other word pairs are universal or merisms (i.e., antonymous binomial conjuncts referring to one whole entity, e.g., heaven and earth for the whole universe). Also, head and foot refers to the whole body, and body and soul denotes every part of a person. Other examples include great/small, good/evil which are of antonyms but have their universal implications. Duke (2003) added that word pairs can be utilized for mnemonic reasons because they help listeners and readers remember some rituals or ideas relevant to their religion. Therefore, word pairs are important in oral communication, especially in sermons.

Duke (2003) listed only word pairs with a minimum of four occurrences to be regarded as stock phrases and to avoid any occurrence that might result from "causal affinity" (p. 37). Nevertheless, he stated that Biblical scholars never set a threshold of occurrences. Duke (2003) reported on the frequent occurrence of only 81 word pairs in the Book of Mormon. Examples of investigated word pairs and phrases are good/bad, old/young, strong/mighty, life/death, eat/drink, hunger/thirst, faith/works, the poor and the needy, and the sick and the afflicted. Duke (2003) commented that some word pairs such as gold/silver are more frequent than others because of their status in a specific culture. The word pair occurred 153 times in the Old Testament and 43 times in the Book of Mormon.

Duke (2003) then categorized word pairs into four categories: (a) synonymous word pairs (e.g., flocks/herds, prophecy/revelation, sins/iniquities), (b) antithetical word pairs or opposites (e.g., heaven/earth, night/day, quick/slow, first/last), (c) correlative pairs (i.e., examples of the same category or co-hyponyms, e.g., gold/silver, fear/tremble), and (d) figurative pairs (e.g., great/abominable, plain/precious, true/living). He also noted that analyzed word pairs may exhibit a different word order (e.g., foolish and vain in place of vain and foolish). Nonetheless, other word pairs never show a shift in word order such as great and abominable. Further, other word pairs were of different forms such as fast/pray and fasting/prayer. As argued by Duke (2003), most of the word pairs he found are frequent in the Old or New Testaments. Duke (2003) recommended that any further investigation of word pairs should consider the variation in word order since some resist word order reversal while others exhibit variation in word order.

Duke $(2003)$ mentioned that Dahood $(1972,1975,1981)$ found about 1,000 similar word pairs in Hebrew and Ugaritic. Duke (2003) also referred to Barney's study (1995) who found 40 word pairs in both the Bible and the Book of Mormon and Canaanite languages (i.e., Semitic languages such as Moabite, Phoenician, Hebrew and Punic) and concluded that his list is not exhaustive. He also made reference to Koskenniemi (1968) who called such pairs formulas since they denote cultural elements and become subject to repetition and preservation by a group of people. Some of Old English word pairs that became part of Modern English include part/parcel, really/truly, words/deeds, etc. Other word pairs that occur in the scriptures and can be found in other cultures are gold/silver and eat/drink.

One more study is by Talshir (2013) who examined binomials occurring at least twice in Late Biblical Hebrew, Qumran, Tannaitic literature (i.e., old literature reflecting a period in the Jewish history between 10-220 C.E.) and Amoraic literature (i.e., old literature reflecting a period in the Jewish history between 220 to 300-500 C.E.). The analyzed binomials are either not found in Classical Hebrew or show a shift in their word order. Further, other binomial words are connected by a waw, of a fixed word order, contributed one meaning, and belonged to the same semantic field. The binomials have been divided into two groups. The first group includes literary or stylistic phrases (e.g., figures of speech such as power and strength and young and old), whereas the second is of social and political phrases that reflect a specific time period (e.g., Judah and Benjamin, priests and

Page | 211 
Levites). Talshir (2013) did not consider only binomials but also construct phrases (e.g., in strong power), phrases with pronominal suffixes (e.g., his mighty power), and word pairs in parallel structures. According to Talshir (2013), binomial words can be near synonyms, antonyms, or co-hyponyms (i.e., complementary). Talshir (2013) focused on which constraints determine word order and reported on how frequent such constructions in religious writing. Talshir (2013) noted that power and strength and its variant strength and might occurred twice in the Hebrew Bible and twice in Qumran. Additionally, it occurred four times in the Tannaitic and Amoraic literature as strength and might and strongly and mightily. The binomial gladness and joy occurred 12 times and twice in the opposite order if it came as part of a longer string. It is used only once in Qumran. Regarding women and children without pronominal suffixes, it occurred eight times in Classical Hebrew and three times with no pronouns and in the opposite word order in Late Biblical Hebrew. Talshir (2013) stated that additional elements in a binomial will allow for its reversibility. Examples included the variants (i.e., your wives, children and your children, your wives). The binomial (i.e., women and children) appeared in Qumran twice as part of a longer sequence. In Tannaitic literature, the binomial appeared twice in different word orders. However, in Amoraic literature, the classical word order prevailed. Talshir (2013) commented that a binomial with a specific word order could reflect a specific time period.

As for antonyms such as little or big, great or small, larger and smaller, small and great, large and small, great and small, they occurred in both word orders and it is more commonly for small or little to precede great or big. In Qumran, the binomial the inferior his superior was found once. In Rabbinic literature, it is more common for big to precede small but binomials of both word orders were found. Binomials such as adult and minor sons, large or small, small or large, infants and adults, not a large and not a small are examples. As for young and old, it was used nine times in the classical books. As for the literature, the binomial with the opposite word order gained ground on four occasions and two times in Qumran. In Rabbinic literature, old and young appeared. Regarding the culture-specific binomial (i.e., priests and Levites), it was used 37 times in Late Biblical Hebrew and only once in Classical Hebrew. In Qumran, the binomial is treated as one unit, whereas in Tannaitic literature, it was employed for argumentation. As for Amoraic literature, the phrase was rarely used. Used as a single unit, the other culture-specific binomial (i.e., Judah and Benjamin) was found in Late Biblical Books with a total of 15 occurrences and it was used only once in the reverse order. The same binomial emerged also in Qumran literature and Rabbinic literature. Talshir (2013) concluded that cultural binomials do not belong to any semantic category, and that the six investigated binomials are either not used or rarely used in Classical Hebrew or exhibit the opposite word order. He also added that binomials characterize a specific time period where linguistic changes have been added gradually to religious books.

Another study is by Landau (2017) who examined the meanings of the words "morning" and "evening" in parallel structures in Biblical poetry. Landau (2017) noted that the word pair occurred twice as morning and evening and three times as evening and morning. He explained that the word pair is used as a merism referring to either "a day" or "a night" or as an instance of sequential parallelism to give the meaning that such a sequence of events lasts for a brief moment. Further, such word pairs can be also considered as an example of synonymous parallelism only when religious writers want to wrap up discussions in a faithful manner.

\section{Religious Binomials in Arabic}

Studies on Arabic binomials have explored their grammatical and semantic categories (e.g., Gorgis \& Al-tamimi, 2005; Khairy \& Hussein, 2013), constraints on their word order (e.g., Gorgis \& Al-tamimi, 2005; Kaye, 2015; Mahdi, 2016; Saaed, 2010), strategies used to translate them (e.g., Al-Jarf, 2016; Mohammad et al., 2010), distribution of binomials in males' and females' speeches (Ammari, 2015), and EFL learners' awareness of such constructions (Alotaibi \& Alotaibi, 2015; Jasim, 2009). However, there is no single study that explored binomials in religious texts except for one by Mahdi (2016).

Mahdi (2016) analyzed all the binomial expressions in Du'à Al-Șabāh by Imam Ali bin Abi Talib. The analysis focused on determining binomials' ordering constraints, their semantic categories, and types of word classes binomial members belong to.

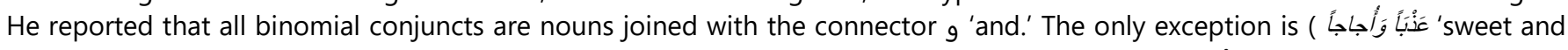

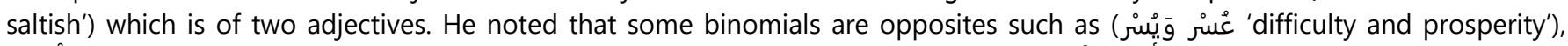

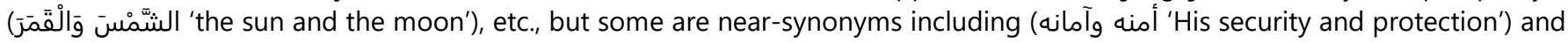
(الموت والفناء 'death and mortality').

As for ordering constraints, phonologically, the Short-Before-Long Principle (i.e., the first word is phonologically shorter than the

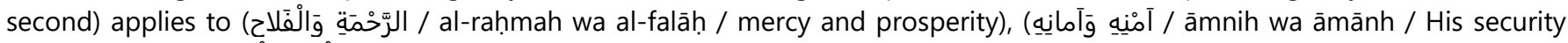

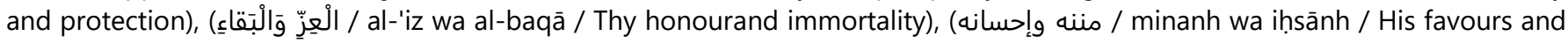
kindness), (يده وسلطانه / yadah wa sulțānih / His Control and Power), (النفس والشيطان / al-nafs wa al-shyțān / the soul and Satan), ( زللي وخطأي / zalali wa khaț'aĩ / the slips and errors I have committed), (مطلوبي ومنقان / mațlubi wa munāy / my utmost wish and desire), (منقلبي ومثواي / munqlabī wa mathwāy / my ultimate end and stable abode), (الطلب / والوغلواي / al-țalab wa alwaghūl / seeking and entering), (الدين والدنيا / al-dīn wa al-dun'yā / in religion and in this world), (عذبا وأجاجا / 'adhban wa ujajan / 
sweet and saltish), (الموت والفناء / al-mawt wa al-fānā / death and mortality), (أملي ورجائي / amlī wa rajāy / my hope and desire), etc.

Semantically, to explain the irreversibility (i.e., fixedness in word order) exemplified by (النَفْسِ وَالشَّيْطِنِ / al-nafs wa al-shyțān / the soul and Satan), (الشمس والقمر / al-shams wa al-qamara / the sun and the moon), (وانئ / ورائي / amlī wa rajāy / my hope and desire), (الدين والدنيا / al-dīn wa al-dun'yā / in religion and in this world), (لطفيك / لطفيك / ورأفتك) / lutfik wa ra'fatik / Thy gentleness and grace), (الأمل والمنى / al-amal wa al-muná / hope and aspirations), (الرحمة والفناح) / al-rahmah wa al-falāḥ /mercy and prosperity), (أمنه وآمانه / amnh wa āmānh / His security and protection), Mahdi (2016) argued that the first item is more powerful or salient than the second. However, the order in (الدّين وَالدُّنْيا / al-dīn wa al-dun'yā / in religion and in this world) is

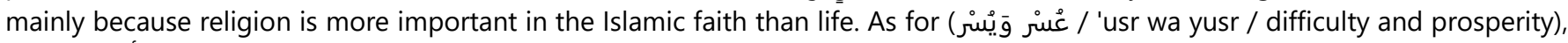

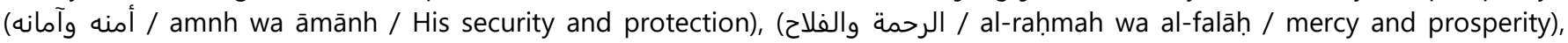

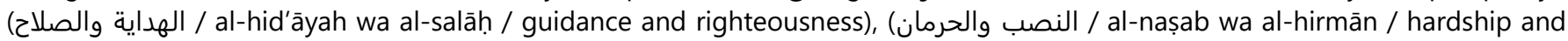
deprivation), (مطلوبي ومناي / mațlubi wa munāy / my utmost wish and desire), (منقلبي ومثوان / manqlaī wa mathwāy / my

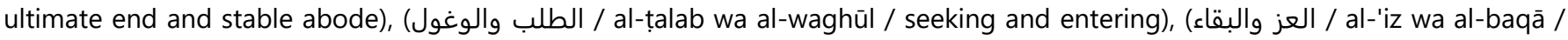
Thy honourand immortality), (الموت والفناء / al-mawt wa al-fānā / death and mortality), the principle of iconic sequencing (i.e., logical order of events) justified placing the first word before the other. For example, in the case of (عَسْر وَيْسْر / 'usr wa yusr / difficulty and prosperity), the occurrence of hardship before ease is logical since relief is described so only after time of hardship.

Additionally, the principle of markedness may explain the word order in (يده وسلطانه / yadah wa sulțānih / His Control and Power), (الرحمة والفلاح / al-raḥmah wa al-falāḥ /mercy and prosperity)، (الهداية والصلاح / al-hid'āyah wa al-salāḥ / guidance and

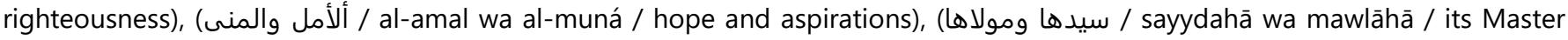
and Lord), (سيدي ومولاي / sayydi wa mawlāy / my Master and my Lord), (معتمدي ورجائي / mu'tamadī wa rajāy / my Support and my Hope), (الطلب والوغول / al-țalab wa al-waghūl / seeking and entering) since the first order is more frequent than the second. Besides markedness, alphabetical reasons determine the order in (ظنونها ومناها / zununahā wa munahā / its own notions and

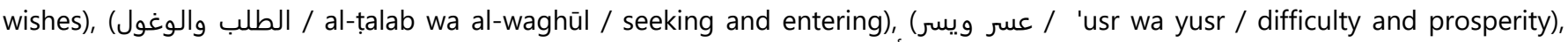
(سيدها ومولاها / sayydahā wa mawlāhā / its Master and Lord), (أملي ورجائي / ama rajāy / my hope and desire).

\section{Conclusion and Suggestions for Further Research}

As shown above, Duke (2003) tried to list all the word pairs in the Book of Mormon, whereas Talshir (2013) initiated a diachronic investigation of six binomial groups with their variants in Hebrew religious texts. However, it is apparent that Talshir (2013) confused lemmas with types since little or big, great or small, large and small, great and small have been treated as variants of the lemma (old and young). Nevertheless, the reviewed studies give a different categorization to binomials but added the category of figurative binomials and culture-specific ones (e.g., Duke, 2003; Talshir, 2013). In addition, binomials in religious texts can be analyzed in terms of specific semantic fields (e.g., Duke, 2003; Talshir, 2013).

In general, studies on religious binomials explored frequent pairs. Moreover, Duke (2003) set a minimum number of occurrences and noted that culture-specific binomials are more frequent than others. On the other hand, Landau (2017) explored one reversible binomial (i.e., morning and evening and evening and morning). Further, some studies focused on binomials' functions (e.g., Duke, 2003; Talshir, 2013) or their theological significance (Duke, 2003). Additionally, while Duke (2003) pointed to the importance of identifying reasons that determine variation in word order, Talshir (2013) summarized the constraints that dictate word order. However, his investigation lacks a rigorous statistical account of data. More significantly, Landau (2017) reported that each occurrence of a word pair gives a different meaning because of contextual reasons. It is important to note that studies on the Hebrew Bible drew researchers' attention to the study of binomials as an important feature of religious texts in Semitic languages. Also, in one type of texts, there will be different types of binomials that may serve different functions in which some are culture-specific, and others are considered to be universal (Bach, 2017). On the other hand, there is only one study on Arabic religious binomials by Mahdi (2016), and it explored binomials in terms of their syntactic and semantic structure besides constraints governing word order. Thus, because religious binomials in Arabic are under-researched, other relevant areas of research may address the alliterative nature of binomials in the Holy Qur'ān, factors determining the order of binomial words in the Holy Qur'ān and Hadīth, and their semantic and grammatical categories.

Conflicts of Interest: The author declares no conflict of interest. 


\section{References}

[1] Abraham, R. D. (1950). Fixed order of coordinates. Modern Language Journal, 34, 276-287. https://doi.org/10.1111/j.1540-

4781.1950.tb06011.x

[2] Al-Jarf, R. (2016). Translation of English and Arabic binomials by advanced and novice student translators. In L. Ilynska \& M. Platonova (Eds.), Meaning in translation: Illusion for precision (pp. 281-298). Cambridge Scholars Publishing.

[3] Ammari, E. H. (2015). English Siamese twins and their cohorts exemplified in selective speeches of the twentieth century. International Journal of Applied Science and Technology, 5(5), 92-100. http://www.ijastnet.com/journals/Vol_5_No_5_October_2015/12.pdf

[4] Alotaibi, A. M., \& Alotaibi, M. A. (2015). The acquisition of binomials by Kuwaiti EFL learners. International Journal of English Linguistics, 5(3), 63-71. https://doi.org/10.5539/ijel.v5n3p63

[5] Avishur, Y. (1984). Stylistic studies of word-pairs in Biblical and ancient Semitic literatures. Butzon \& Bercker.

[6] Baalbaki, R. M. (1990). Dictionary of linguistic terms (English-Arabic-Arabic). Dar El-ilm.

[7] Bach, U. (2017). Functions of binomials in Early Modern English Protestant wills. In J. Kopaczyk \& H. Sauer (Eds.), Binomials in the history of English: Fixed and flexible (pp. 1-23). Cambridge University Press. https://doi.org/10.1017/9781316339770.001

[8] Bakir, M. (1999). Ordering principles in conjoined lexical pairs. Linguistic Research, 4(1-2), 9-33.

[9] Barney, K. L. (1995). Poetic diction and parallel word pairs in the Book of Mormon. Journal of Book of Mormon Studies, 4(2), $15-81$.

[10] Birdsong, D. (1979). Psycholinguistic perspectives on the phonology of frozen word order [Unpublished doctoral dissertation]. Harvard University.

[11] Bolinger, D. (1962). Binomials and pitch accent. Lingua, 11, 34-44. https://doi.org/10.1016/0024-3841(62)90011-6

[12] Borchers, M. (2007). Middle English phraselogy: Problems identifying the source(s). Proceedings of LingO 2007, 27-34.

[13] Carvalho, L. (2008). Translating contracts and agreements: A corpus linguistics perspective. Culturas Juridias, 3(1), 1-15.

[14] Cooper, W., \& Ross, J. (1975). World order. In R. Grossman, L. J. San, \& T. Vance (Eds.), Papers from the parasession on functionalism (pp. 63111). Chicago Linguistic Society.

[15] Copestake, A., \& Herbelot, A. (2011). Exciting and interesting: Issues in the generation of binomials. Proceedings of the UCNLG+Eval: Language Generation and Evaluation Workshop (pp. 45-53). Association for Comutational Linguistics.

[16] Cummings, M. (1980). Paired opposites in Wulfstan's Sermo Lupi ad Anglos. Revue de l'Université d'Ottawa, 50, $233-243$.

[17] Dahood, M. (1972). Ugaritic-Hebrew parallel pairs. In L. R. Fisher (Ed.), The Ras Shamra parallels: Texts from Ugarit and the Hebrew Bible (pp. 1-39). Pontifical Biblical Institute.

[18] Dahood, M. (1975). Isaiah 51,19 and Sefîre III 22. Biblica, 56(1), 94-95. http://www.jstor.org/stable/42611474

[19] Dahood, M. (1981). Eblaite ì-du and Hebrew 'èd, "Rain Cloud". The Catholic Biblical Quarterly, 43(4), 534-538.

http://www.jstor.org/stable/43716131

[20] Duke, J. T. (2003). Word pairs and distinctive combinations in the Book of Mormon. Journal of Book of Mormon Studies (1992-2007), 12(2), 32-41. https://scholarsarchive.byu.edu/jbms/vol12/iss2/5/

[21] Fenk-Oczlon, G. (1989). Word frequency and word order in freezes. Linguistics, 27, 517-556. https://doi.org/10.1515/ling.1989.27.3.517

[22] Fowler, H.W. (1965). Fowler's dictionary of modern American usage.

https://books.google.com.sa/books?id=AvmzBgAAQBAJ\&pg=PA175\&lpg=PA175\&dq=fowler+siamese +twins\&source=bl\&ots=gJt8P-

IsAg\&sig=H4nAGk8uFOrT-SwwM2ETB8N45mY\&hl=ar\&sa=X\&ved=0ahUKEwjo-

uSGwsrbAhXIQBQKHXvRAFgQ6AEIWDAJ\#v=onepage $\& q=$ fowler\%20siamese\%20twins $\& f=$ false

[23] Gorgis, D. T., \& Al-tamimi, Y. (2005). Binomials in Iraqi and Jordanian Arabic. Journal of Language and Linguistics, 4(2), $135-151$.

[24] Green, V., \& Birdsong, D. (2018). Intuitions for phonological constraints in binomials: A psycholinguistic investigation. Language Sciences, 66, 116-134. https://doi.org/10.1016/j.langsci.2018.02.004

25] Gustafsson, M. (1975). Binomial expressions in present-day English: A syntactic and semantic study. Turun Yliopisto.

[26] Gustafsson, M. (1984). The syntactic features of binomial expressions in legal English. Text, 4(1-3), 123-142.

https://doi.org/10.1515/text.1.1984.4.1-3.123

[27] Hamdan, J. M., \& Abu Guba, M. N. (2007). The treatment of binomials in monolingual and bilingual dictionaries. International Journal of Arabic-English Studies (IJAES), 8, 105-122. http://www.ijaes.net/article/FullText/8?volume=8\&issue=1

[28] Jasim, B. (2009). Investigating the advanced Iraqi EFL learners' mastery of using English irreversible binomials. Adab Al-Rafidayn, 53, 1-30.

[29] Kadi, S. (1988). English and Arabic binomials. Al-Abhath, 36, 43-53.

[30] Kaye, A. S. (2015). Cultural ingredients in Arabic lexical pairs (binomials). WORD, 60(1), 65-78.

https://doi.org/10.1080/00437956.2009.11432593

[31] Khairy, N., \& Hussein, N. (2013). A syntactic and semantic study of 'binomial expressions' in English and Arabic legal documents. Journal of Human Sciences, 1(14), 345-361. https://iasj.net/iasj?func=article\&ald=85868

[32] Kopaczyk, J., \& Sauer, H. (2017). Defining and exploring binomials. In J. Kopaczyk, \& H. Sauer (Eds.), Binomials in the history of English: Fixed and flexible (pp. 1-23). Cambridge University Press. https://doi.org/10.1017/9781316339770.001

[33] Koskenniemi, I. (1968). Repetitive word pairs in Old and Early Middle English prose. Turun Yliopisto.

[34] Landau, E. (2017). The word-pair morning/evening as a parallel word-pair in Biblical poetry. Jewish Bible Quarterly, 45(4), 260-268.

https://jbqnew.jewishbible.org/assets/Uploads/454/jbq_454_Landauwordpair.pdf

[35] Landsberg, M. (1995). Semantic constraints on phonologically independent freezes. In M. Landsberg (Ed.), Syntactic iconicity and linguistic freezes: The human dimension (pp. 65-78). De Gruyter Mouton. https://doi.org/10.1515/9783110882926.65

[36] Leisi, E. (1947). Die tautologischen Wortpaare in Caxton's 'Eneydos': Zur synchronischen Bedeutungs und Ursachenforschung [The tautological word pairs in Caxton's 'Eneydos': On synchronic meaning and causal research]. Murray.

[37] Lohmann, A. (2012). A processing view on the order in reversible and irreversible binomials. Views (Vienna English Working Papers), 21(1), 25-50.

[38] Mahdi, A. (2016). Binomial expressions with reference to Du'aa as-Sabah (The Morning Invocation) by Imam Ali bin Abi Ṭalib (AS). Journal of University of Babylon, 24(1), 188-197. https://www.iasj.net/iasj/article/108209 
[39] Malkiel, Y. (1959). Studies in irreversible binomials. Lingua, 8, 113-160. https://doi.org/10.1016/0024-3841(59)90018-X

[40] Mollin, S. (2012). Revisiting binomial order in English: Ordering constraints and reversibility. English Language and Linguistics, 16(1), 81-103. https://doi.org/10.1017/S1360674311000293

[41] Mollin, S. (2014). The (ir)reversibility of English binomials: Corpus, constraints, developments. John Benjamins Publishing Company. https://doi.org/10.1075/scl.64

[42] Pinker, S., \& Birdsong, D. (1979). Speakers' sensitivity to rules of frozen word order. Journal of Verbal Learning and Verbal Behavior, 18(4), 497-508. https://doi.org/10.1016/S0022-5371(79)90273-1

[43] Saaed, S. (2010). Phonological constraints on binomials in Iraqi Arabic with reference to English. Essex Graduate Student Papers in Language and Linguistics, 12, 81-101.

[44] Talshir, D. (2013). Syndetic binomials in Second Temple Period Hebrew. Hebrew in the Second Temple Period, 108, $225-239$. https://doi.org/10.1163/9789004254794_017

[45] Tani, A. (2008). The word pairs in The Paston Letters and Papers with special reference to text type, gender and generation. In M. Amano, M. Ogura, \& M. Ohkado (Eds.), Historical Englishes in varieties of texts and contexts (pp. 217-231). Peter Lang.

[46] Tani, A. (2010a). Word pairs in Late Middle English prose [Unpublished doctoral dissertation]. University of Glasgow.

[47] Tani, A. (2010b). Word pairs in Chaucer's Melibee and their variant readings. In O. Imahayashi, Y. Nakao, \& M. Ogura (Eds.), Aspects of history of the English language and literature (pp. 101-113). Peter Lang.

[48] Tiersma, P. M. (1999). Legal language. University of Chicago Press.

[49] Tvedtnes, J. (1997). Word groups in the Book of Mormon. Journal of Book of Mormon Studies (1992-2007), 6(2), $262-268$.

https://www.jstor.org/stable/44758834 